\title{
High Nature Value Farmland: Assessment of Soil Organic Carbon in Europe
}

\author{
Ciro Gardi ${ }^{1 *}$, Giovanna Visioli ${ }^{2}$, Federica D. Conti ${ }^{2}$, Marco Scotti $^{3}$, Cristina Menta ${ }^{2}$ and \\ Antonio Bodini ${ }^{2}$ \\ ${ }^{1}$ Animal and Plant Health (Alpha), European Food Safety Authority, Parma, Italy, ${ }^{2}$ Department of Life Sciences, University of \\ Parma, Parma, Italy, ${ }^{3}$ GEOMAR Helmholtz Centre for Ocean Research Kiel, Kiel, Germany
}

OPEN ACCESS

Edited by:

Urs Feller,

University of Bern, Switzerland

Reviewed by:

Martin Potthoff

Centre of Biodiversity and Sustainable

Land Use, Germany

Geoffrey R. Squire,

James Hutton Institute, UK

*Correspondence:

Ciro Gardi

ciro.gardi@efsa.europa.eu

Specialty section:

This article was submitted to Agroecology and Land Use Systems,

a section of the journal

Frontiers in Environmental Science

Received: 16 October 2015 Accepted: 08 June 2016

Published: 21 June 2016

Citation:

Gardi C, Visioli G, Conti FD, Scotti M, Menta C and Bodini A (2016) High

Nature Value Farmland: Assessment of Soil Organic Carbon in Europe.

Front. Environ. Sci. 4:47. doi: 10.3389/fenvs.2016.00047
High Nature Value Farmland (HNVF) is commonly associated with low intensity agricultural systems. HNVFs cover $\sim 32 \%$ of the agricultural land in Europe and are of strategic importance for the European Union policy since they are reservoirs of biodiversity and provide several ecosystem services. Carbon sequestration is an important service that can be supplied by HNVFs as addressed in this study. Considering soil carbon content as a proxy for soil carbon storage, we compare HNVFs with soils that undergo more conventional land management (nHNVFs) and study the consequences of diverse land uses and geographic regions as additional explanatory variables. The results of our research show that, at the European level, organic carbon content is higher in HNVF than in nHNVF. However, this difference is strongly affected by the type of land use and the geographic region. Rather than seeing HNVF and nHNVF as two sharply distinct categories, as for carbon storage potential, we provide indications that the interplay between soil type (HNVF or nHNVF), land use, and geographic region determines carbon content in soils.

Keywords: ecosystem services, HNV farmland, land use, LUCAs dataset, soil carbon storage

\section{INTRODUCTION}

The term High Nature Value Farmland (HNVF) was introduced in the early 1990s (Baldock et al., 1993; Beaufoy et al., 1994) to underline the relationship between agriculture and biodiversity (Trisorio and Borlizzi, 2011). Andersen et al. $(2003,2007)$ defined HNVFs as "those areas in Europe where agriculture is a major (usually the dominant) land use and where that agriculture supports, or is associated with, either a high species and habitat diversity or the presence of species of European conservation concern, or both." HNVFs comprise small patches of semi-natural land covering the farmed landscape. Despite the little dimension, such patches effectively contribute to the conservation of biodiversity in agricultural areas (Beaufoy et al., 1994; Plieninger and Bieling, 2013). According to Lomba et al. (2014) landscapes of high value for nature conservation in Europe comprise: (1) farmlands under low intensity management, with a high proportion of associated semi-natural vegetation used as a forage or fodder resource; (2) farmlands characterized by low intensity management and mosaics of semi-natural and cultivated land; and (3) farmlands that provide habitat to one or more species that are rare either at the European or on a global scale. It has been demonstrated that HNVF is in general associated to low input agricultural systems (Pointereau et al., 2007). HNVF is envisaged as a way to maintain and improve biodiversity as well as to promote ecosystem restoration, bringing also socio-economic benefits (Peneva et al., 2014). 
Ecosystem services (ES) depend on ecosystem functions and are beneficial to the human population (Daily et al., 1997; MEA, 2005; Lavelle et al., 2006). Among the key services, climate regulation is one of the most important both on global and European scale. Carbon sequestration is a fundamental process for this service to be effective and soils possess a high potential storage capability. They are the major reservoirs of terrestrial carbon with an estimated mass that amounts globally to 1200$1600 \times 10^{9} \mathrm{Mg}$ of carbon (Eswaran et al., 1993; Batjes, 1996; Zech et al., 1997). Several studies aimed to estimate soil organic carbon (SOC) content within the ecosystem services framework (Egoh et al., 2008, 2009; Naidoo et al., 2008). Besides climate regulation, soil carbon is crucial for the maintenance of soil fertility and the prevention of erosion and desertification (Palm et al., 1997), therefore providing further ecosystem services on the local as well as the global scale (Marks et al., 2009).

Intensive agriculture, characterized by a massive use of inputs (fertilizers, herbicides, pesticides, etc.) and practices (tillage, different rotations per year, irrigation, etc.) to maximize harvest, has negative local, regional, and global consequences on above and below-ground biodiversity (Tsiafouli et al., 2015), on soil organic matter and thus on soil carbon content (Matson et al., 1997). Accordingly, it reduces the quality of soils (Karlen et al., 1997). In particular, carbon loss is clear in agroecosystems, but a wise management (e.g., no-till, cover crops, green, or animal manure) could reduce the rate and the amount of this loss (Matson et al., 1997; Naidoo et al., 2008). Thus, a central aspect of interest is to assess whether and how different land management types and forms of land use can affect the level of organic carbon in soils. This will allow the design and implementation of management strategies for carbon preservation in agricultural soils. In this study we address this matter by comparing the current carbon content of HNVF and nHNVF soils. The hypothesis we tested was the possible influence of land management (HNVF vs. nHNVF), and the interactions with land use/crop types and geographic regions on soil carbon content. In particular, we address the following questions: (a) is there a significant difference between HNVF and nHNVF in terms of carbon content? (b) Does the carbon content in HNVFs and nHNVFs depend on land use/crop types and geographical distribution of the soils? To answer these questions we exploited the LUCAS dataset, an extensive database that contains detailed information on land cover and land use across all European Union member states.

\section{MATERIALS AND METHODS}

\section{Sampling and Soil Analyses}

LUCAS (Land Use/Cover Area frame statistical SurveyEUROSTAT, 2015) is a survey created to perform a regular monitoring across all European Union member states. It contains information on land cover and land use that was gathered by direct field analysis of topsoil (Panagos et al., 2013). LUCAS was coordinated by the European Commission's Joint Research Centre in 2009 and 2011; field activities (survey and sampling) were carried out by professional consultancy companies operating at level of the member states. The purpose of the survey was to collect soil samples in 23 member states of the European Union (EU), and analyze them to characterize the main chemical and physical features. Although LUCAS samples were taken from all types of land use and land cover, the agricultural areas were the most deeply investigated. Topsoil samples (0$20 \mathrm{~cm}$ ), each consisting of five sub-samples, were collected from $\sim 10 \%$ of the 265,000 LUCAS survey points, resulting into a total of $\sim 20,000$ samples. The selection of sampling points was designed to be representative of the agricultural land uses of the different countries using a stratified sampling scheme that took advantage of land use and terrain information. To obtain a harmonized dataset with pan-European coverage, all the 20,000 soil samples were analyzed in a sole ISO-certified laboratory. The soil parameters analyzed were: coarse fragments, particle size distribution, $\mathrm{pH}\left(\mathrm{CaCl}_{2}\right), \mathrm{pH}\left(\mathrm{H}_{2} \mathrm{O}\right)$, organic carbon, carbonate, phosphorus, total nitrogen, extractable potassium, cation exchange capacity, and multispectral properties. For the organic carbon analysis, the soil samples obtained after dry combustion at a temperature of $900^{\circ} \mathrm{C}$ were analyzed in a single ISO certified laboratory using the ISO 10,694 (ISO, 1995) method (Panagos et al., 2013; Tóth et al., 2013). The average density of LUCAS soil points was almost one sample every $200 \mathrm{~km}^{2}$. An elevation comparison was used as additional indicator of representativeness of LUCAS soil point data. Elevation above $1000 \mathrm{~m}$ was considered a non-representative class. For more details about LUCAS data collection see Tóth et al. (2013) and Panagos et al. (2013).

\section{European HNVF Map}

We used a HNVF map that was compiled according to the methodology described in Paracchini et al. (2008). The compilation of such map comprises several steps. The first step for the selection of HNVF areas consisted of the overlay between the CORINE Land Cover (CLC 2000-EEA-ETC/TE, 2002), the Environmental Stratification of Europe Version 6 (Metzger et al., 2005; Jongman et al., 2006) and the country borders. This approach was adopted in the understanding that CLC class itself can be extremely different in terms of management and environmental characteristics across countries. For example, in Greece only the olive groves of Mediterranean Mountains (sensu Environmental Stratification of Europe) are included in HNVF; the same crop in Mediterranean South, Mediterranean North, or Alpine South is excluded. Another example is the case of rice fields: they are included in HNVF in Greece only, whereas in all the other countries they are excluded. This approach could probably be refined and improved by adopting the regional level (corresponding to the NUTS-Nomenclature of Territorial Units for Statistics-2) instead of the national level (NUTS 0), but the purpose of this study was to use the set of data as it was produced by the Joint Research Centre (JRC; Figure 1).

The selection criteria for HNVF (based on expert knowledge) are reported in the Annex II of Paracchini et al. (2008). In addition to the "primarily HNV land" selected according to these criteria, relevant areas for nature conservation across Europe have been added. In particular, the following geographic datasets have been used: (1) NATURA 2000 network; (2) Important Bird Areas (IBAs); (3) Prime Butterfly Areas (PBAs; Van Swaay 


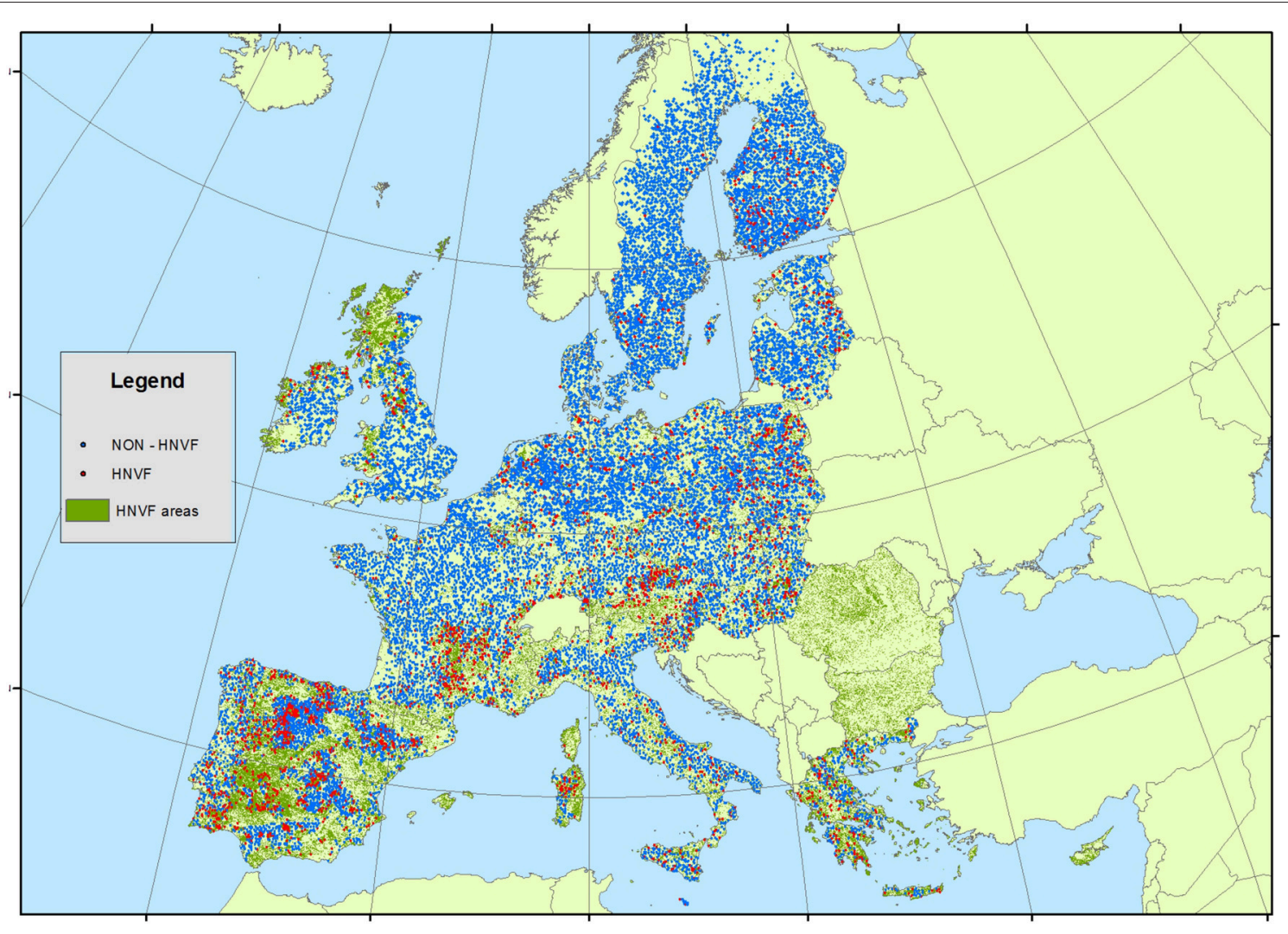

FIGURE 1 | Overlap of LUCAS soil sampling points over HNVF and nHNVF areas.

and Warren, 2003); and (4) national biodiversity datasets (when available). From these databases, agricultural areas relevant for biodiversity conservation but not detectable by the land cover approach have been included. From the national biodiversity datasets of some countries (i.e., Czech Republic, Sweden, Estonia, Lithuania, England) it was possible including in HNVF the seminatural grasslands that otherwise would not have been identified from the Corine Land Cover map.

\section{Data Selection and Analyses}

In order to select and classify the LUCAS soil sampling points, based on their inclusion (or exclusion) within the HNVF areas, the two layers (LUCAS and HNVF) were overlaid using ArcGIS 10.2.

In order to explain the variation in SOC, we exploited the LUCAS dataset using a Generalized Linear Model (GLM) by carrying out regression analysis and ANOVA. Since our objective was to assess whether the organic carbon content in soils depends on the type of land management and whether this dependency may be influenced by the specific land use of the soils and by the geographic region where soils are located, we approached the statistical design considering that we had to test the response of a continuous variable (organic carbon content) to variations of three different predictors (nature of soil management, land use type, and geographic region). Our main factors are: (1) the land management type, with two levels: HNVF and nHNVF; (2) the land use/crop type that includes 10 different levels corresponding to the agricultural practices of Table 1; and (3) the geographical distribution of the soils, with this latter predictor that consists of five levels corresponding to the geographical regions listed in Table 2. Crops are clustered into land use/crop type classes based on similar agronomic practices, while the division into geographical regions was essentially based on aggregation of countries according to the climate.

The form of the model we used is presented according to $\mathrm{R}$ syntax in the Supplementary Material (SM, henceforth). The model considers the organic carbon content as the dependent variable and the predictors are labeled as: (1) nature (HNVF vs. nHNVF); (2) land use; and (3) region. We used a GLM with Gamma family and log link. We selected the best model from all possible combinations of interactions between simple variables (with $\mathrm{x}$ that indicates the interaction between variables), guided by Akaike information criterion (AIC) statistics (Burnham and Anderson, 1998). We completed the analysis by performing a Tukey post-hoc test to highlight which differences are significant among all possible comparisons that include combinations of the three main factors. This test yielded as many as 6466 comparisons, an indicator of the level of complexity of the model. 
TABLE 1 | Land use/crop types and corresponding classes in the LUCAS dataset.

\begin{tabular}{|c|c|c|c|}
\hline Key & Type of land use/crop type & LUCAS classes & No. samples \\
\hline WSC & Winter/spring cereals & (B11 B12 B13 B14 B15) & 4353 \\
\hline SC & Summer cereals & (B16) & 1095 \\
\hline OC & Oilseed crops & (B31 B32 B33) & 376 \\
\hline RTC & Root/tuber crops & (B21 B22 B23) & 755 \\
\hline VIC & Vegetable and industrial crops & (B41 B42 B43 B44 B45) & 261 \\
\hline FC & Forage crops & (B51 B52 B53 B54 B55) & 649 \\
\hline FB & Fruit and berries & (B71 B72 B73 B74 B75 B76 B77) & 274 \\
\hline V & Vineyards & (B82) & 420 \\
\hline $\mathrm{O}$ & Olive groves & (B81) & 315 \\
\hline G & Grasslands & (E10 E20) & 3935 \\
\hline
\end{tabular}

Code for each one of the 10 classes (Key) and number of samples are indicated.

TABLE 2 | Geographical regions used to cluster EU countries.

\begin{tabular}{|c|c|c|}
\hline Key & Geographic region & No. samples \\
\hline CON & Continental Europe (Austria, Czech Republic, Germany, Hungary, Poland, Slovakia and Slovenia) & 3802 \\
\hline ECO & Atlantic Europe (Belgium, France with latitude $>44.00$, Luxembourg, Netherlands, Portugal, Spain with latitude $>42.50$ ) & 2806 \\
\hline BS & Baltic and Scandinavia (Denmark, Estonia, Finland, Latvia, Lithuania, and Sweden) & 1470 \\
\hline MED & Mediterranean (Greece, Italy, Malta, Spain with latitude <42.50, France with latitude <44.00) & 3352 \\
\hline UKI & UK and Ireland & 1003 \\
\hline
\end{tabular}

Number of samples per region and code (Key) are provided.

\begin{tabular}{lccccc}
\hline TABLE 3 | Summary of the ANOVA carried out with GLM. & \\
\hline & Df & Sum Sq & Mean Sq & F-value & $\boldsymbol{p}$ \\
\hline Nature & 1 & 187,928 & 187,928 & 134.22 & $<0.001$ \\
Land use & 9 & $1,562,022$ & 173,558 & 123.96 & $<0.001$ \\
Region & 4 & $1,046,665$ & 261,666 & 186.89 & $<0.001$ \\
Nature $\times$ land use & 9 & 61,003 & 6778 & 4.84 & $<0.001$ \\
Nature $\times$ region & 4 & 197,639 & 49,410 & 35.29 & $<0.001$ \\
Land use $\times$ region & 30 & 192,462 & 6415 & 4.58 & $<0.001$ \\
Nature $\times$ land use $\times$ region & 24 & 50,716 & 2113 & 1.51 & 0.053 \\
\hline
\end{tabular}

The symbol $x$ stands for an interaction between explanatory variables.

\section{RESULTS}

The outcomes of the ANOVA are summarized in Table 3.

From Table 3 there is compelling evidence that all the three main factors are significant. So the level of organic carbon in European soils significantly depends on whether the nature of management is HNVF or nHNVF, what crop type they host (see Table 1), and where they are located within the geographic subdivision we considered (see Table 2). All two-way interactions are highly significant and the three-way interaction is significant at the 0.1 level of probability.

Table S1 presents all the differences in the mean values between the levels of the main factors and the related $95 \%$ confidence interval (CI). This output highlights that HNVF soils are significantly richer in carbon content than soils nHNVF
(nHNVF-HNVF $\left.=-10.48 \mathrm{~g} \mathrm{SOC} \mathrm{kg}^{-1}, p<0.001\right)$. The differences between the 10 levels that characterize the main factor land use were ascertained by performing multiple Tukey comparisons and as many as 17 out of 45 comparisons yielded significant differences (see Table S1). These significant results highlight that grassland soils are richer in carbon than soils hosting any other type of crop. This holds also for soils hosting forage crops: they store more carbon than any other crop except for grasslands. The differences between grasslands and other

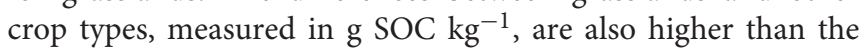
differences observed between FC and the other crop types. All the other comparisons were not significant (Table S1). Nine out of 10 comparisons between geographic regions (Table S1) showed significant differences. A careful inspection of these outcomes reveals that soils (both HNVF and nHNVF) in United Kingdom and Ireland (UKI) contain significantly more carbon than soils in the other regions. On the contrary, soils in the Mediterranean region (MED) contain significantly less carbon than soils in any other region. Baltic and Scandinavian soils have more carbon than Atlantic Europe (ECO), Continental Europe (CON), and MED soils but less than UKI. Finally, it appears that no difference characterizes soils of the Continental Europe compared to soils of the Atlantic Europe. Moreover, we observed that the interactions between explanatory variables resulted significant. This means that the effect that each main factor has on the dependent variable (carbon in soils) is affected by the other factors as well. Table 4 shows how the performance of HNVF soils in retaining carbon depends on the geographical region with differences in SOC between soils 
TABLE 4 | Summary of the differences between the average amount of carbon in HNVF and nHNVF soils in the five geographical regions.

\begin{tabular}{|c|c|c|c|c|}
\hline & \multirow{2}{*}{$\begin{array}{l}\Delta \text { SOC } \\
g_{\text {kg }}^{-1}\end{array}$} & \multicolumn{2}{|c|}{$95 \% \mathrm{Cl}$} & \multirow[t]{2}{*}{$p$} \\
\hline & & Lower & Upper & \\
\hline (BS) nHNVF-HNVF & -10.87 & -20.36 & -1.38 & 0.011 \\
\hline (CON) nHNVF-HNVF & -15.15 & -20.16 & -10.14 & $<0.001$ \\
\hline (UKI) nHNVF-HNVF & -68.29 & -84.86 & -51.73 & $<0.001$ \\
\hline (MED) nHNVF-HNVF & -7.92 & -12.91 & -2.94 & $<0.001$ \\
\hline (ECO) nHNVF-HNVF & -11.06 & -17.34 & -4.79 & $<0.001$ \\
\hline
\end{tabular}

nHNVF and soils HNVF that vary in magnitude within each region.

In all regions soils HNVF contain more carbon than nHNVF. The distributions of HNVF and nHNVF for the different regions are given as box plots in Figure S1. Table 4 clearly shows that the difference between HNVF and nHNVF is much higher in UKI region than in the other areas $\left(68.29 \mathrm{~g} \mathrm{SOC} \mathrm{kg}^{-1}\right)$. In the Mediterranean region this difference is less than $10 \mathrm{~g} \mathrm{SOC} \mathrm{kg}^{-1}$ and in Baltic and Scandinavia the difference is less significant $(p=0.011)$.

If within all geographical regions the soils HNVF contain more carbon than nHNVF, when these two categories are compared considering each crop type across regions only grassland shows a significant difference in favor of HNVF (nHNVF-HNVF $=-9.92 \mathrm{~g} \mathrm{SOC} \mathrm{kg}^{-1}, p<0.001$ ). Finally, the comparison regarded HNVF and nHNVF across regions and crop types (three way interactions). Figure 2 helps to disentangle this information. It shows two charts for each region, one for HNVF and the other for nHNVF; each chart informs us about the distribution of organic carbon associated to the different crop types (land uses). For every single box plot we added the mean value and the standard deviation of the distribution it describes. Also, we depicted a common reference line that shows the HNVF overall mean value.

The results of the Tukey test are presented in Figure S2 in the form of upper triangular and squared color tables to facilitate the interpretation. They can be combined with Figure 2 to understand the effects of three-way interactions. From Figure 2 it appears that in all the regions, except for the Baltic and Scandinavia, grasslands contain more organic carbon than soils hosting other crops (in both HNVF and nHNVF). However, as Figure S2 illustrates, not all the contrasts in which grasslands are compared with other crop types for both HNVF and nHNVF soils yielded significant differences. This applies to all regions. In what follows we summarize some of the most noteworthy outcomes. In the UKI region grassland HNVFs store more organic carbon than grassland nHNVFs, and they contain more organic carbon than the soils hosting other crops. These latter are all of the type nHNVF since HNVF in UKI hosts only grasslands and some WSC. Also, grasslands in the UKI region are significantly richer in carbon than grasslands in other regions, as shown in Table 5. This table also shows that grassland nHNVFs in the UKI region contain more carbon than grassland HNVFs

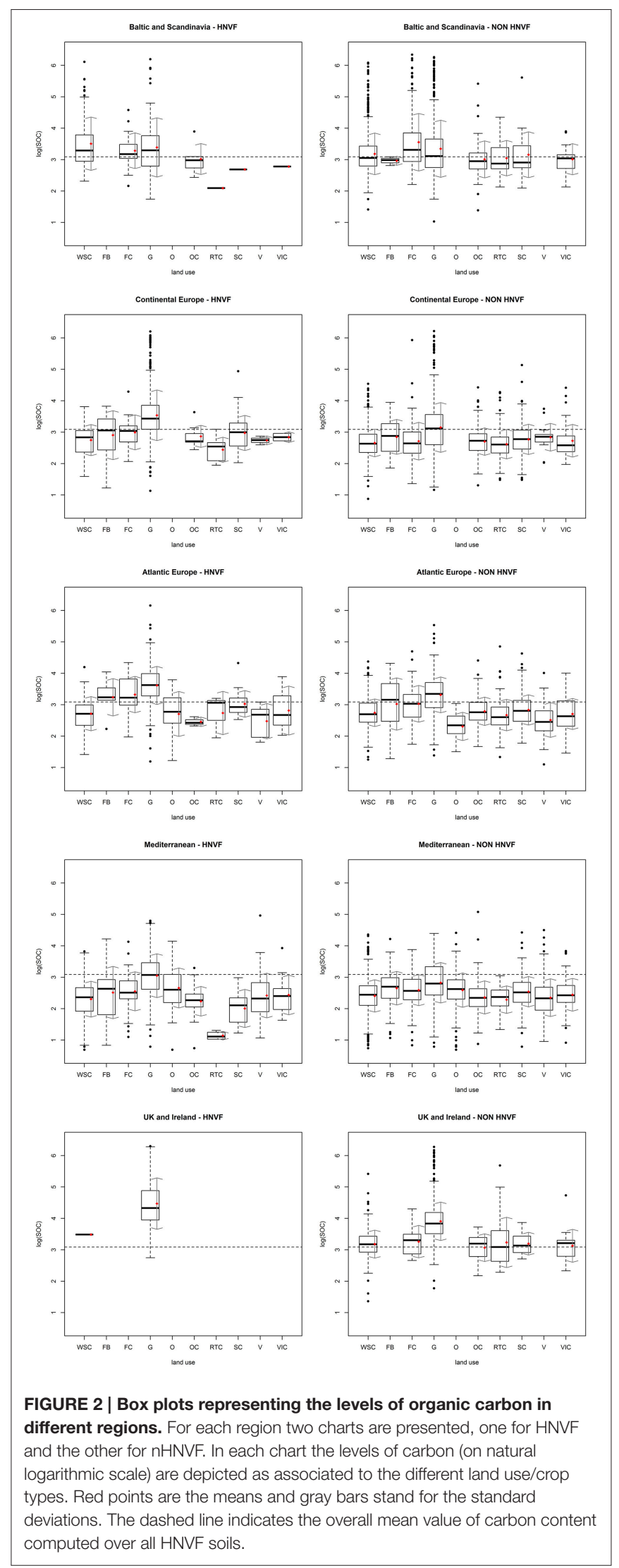


TABLE 5 | Significant differences between grasslands UKI (both HNVF and nHNVF) and grassland HNVFs in the other regions.

\begin{tabular}{|c|c|c|c|c|}
\hline & \multirow{2}{*}{$\begin{array}{l}\Delta \mathrm{SOC} \\
\mathrm{g} \mathrm{kg}^{-1}\end{array}$} & \multicolumn{2}{|c|}{$95 \% \mathrm{Cl}$} & \multirow[t]{2}{*}{$p$} \\
\hline & & Lower & Upper & \\
\hline $\mathrm{HNVF} \times \mathrm{G} \times \mathrm{UKI}-\mathrm{HNVF} \times \mathrm{G} \times \mathrm{BS}$ & 74.52 & 46.06 & 102.96 & $<0.001$ \\
\hline $\mathrm{HNVF} \times \mathrm{G} \times \mathrm{UKI}-\mathrm{HNVF} \times \mathrm{G} \times \mathrm{CON}$ & 74.67 & 51.40 & 97.93 & $<0.001$ \\
\hline $\mathrm{HNVF} \times \mathrm{G} \times \mathrm{UKI}-\mathrm{HNVF} \times \mathrm{G} \times \mathrm{ECO}$ & 81.72 & 57.58 & 105.84 & $<0.001$ \\
\hline $\mathrm{HNVF} \times \mathrm{G} \times \mathrm{UKI}-\mathrm{HNVF} \times \mathrm{G} \times \mathrm{MED}$ & 99.94 & 74.85 & 125.03 & $<0.001$ \\
\hline$n H N V F \times G \times U K I-H N V F \times G \times M E D$ & 36.36 & 22.72 & 49.98 & $<0.001$ \\
\hline$n H N V F \times G \times U K I-H N V F \times G \times U K I$ & -63.59 & -86.71 & -40.45 & $<0.001$ \\
\hline$n H N V F \times G \times U K I-H N V F \times G \times E C O$ & 18.13 & 6.35 & 29.90 & $<0.001$ \\
\hline$n H N V F \times G \times U K I-H N V F \times G \times C O N$ & 11.08 & 1.21 & 20.95 & 0.005 \\
\hline
\end{tabular}

The non-significant comparison between nHNVF UKI grasslands and grassland HNVFs of the Baltic and Scandinavia is not reported. The table also shows the difference between $n H N V F$ and HNVF for grasslands in the UKI region ( $\left.\triangle S O C=-63.59 \mathrm{~g} \mathrm{~kg}^{-1}, p<0.001\right)$.

TABLE 6 | Differences and 95\% confidence intervals for comparisons between grassland HNVFs and other nHNVF soil types in the United Kingdom and Ireland.

\begin{tabular}{|c|c|c|c|c|}
\hline & \multirow{2}{*}{$\begin{array}{l}\Delta \mathrm{SOC} \\
\mathrm{g} \mathrm{kg}^{-1}\end{array}$} & \multicolumn{2}{|c|}{$95 \% \mathrm{Cl}$} & \multirow[t]{2}{*}{$p$} \\
\hline & & Lower & Upper & \\
\hline$n H N V F \times F C-H N V F \times G$ & -97.06 & -155.12 & -39.00 & $<0.001$ \\
\hline $\mathrm{nHNVF} \times \mathrm{OC}-\mathrm{HNVF} \times \mathrm{G}$ & -103.34 & -139.39 & -67.28 & $<0.001$ \\
\hline$n H N V F \times R T C-H N V F \times G$ & -87.49 & -124.28 & -50.70 & $<0.001$ \\
\hline $\mathrm{nHNVF} \times \mathrm{SC}-\mathrm{HNVF} \times \mathrm{G}$ & -100.77 & -152.25 & -49.29 & $<0.001$ \\
\hline $\mathrm{nHNVF} \times \mathrm{VIC}-\mathrm{HNVF} \times \mathrm{G}$ & -99.77 & -143.70 & -55.83 & $<0.001$ \\
\hline $\mathrm{nHNVF} \times \mathrm{G}-\mathrm{HNVF} \times \mathrm{G}$ & -63.59 & -86.72 & -40.46 & $<0.001$ \\
\hline$n H N V F \times W S C-H N V F \times G$ & -99.88 & -124.00 & -75.75 & $<0.001$ \\
\hline
\end{tabular}

in the other regions. The only exception emerged when we compared grassland nHNVFs in the UKI region with grassland HNVFs of the Baltic and Scandinavia.

Within the UKI region the comparisons between grassland HNVFs and other nHNVF crop types yielded significant differences that are reported in Table 6.

In United Kingdom and Ireland HNVF grasslands show significantly higher carbon content than nHNVF soils (however, it should be noticed that only grasslands and winter spring cereals are present as HNVF in this region). Unlike the UKI region, the Atlantic Europe HNVF hosts a wide range of crop types. Nonetheless, the difference in soil carbon content between HNVF and nHNVF emerges as significant in the case of grassland HNVF only. The differences in the mean carbon content and the 95\% confidence intervals for these comparisons are given in Table 7.

The grassland HNVF contains more carbon than most nHNVF crop types. Non-significant differences emerged, however, when the grassland HNVF was compared with forage crops (FC), fruits and berries (FB), and olive groves (O) nHNVF. Some of these results may appear unexpected, according to the box plots in Figure 2. For example, grassland HNVFs and olive grove nHNVFs are not significantly different $(-21.26 \mathrm{~g}$ SOC $\mathrm{kg}^{-1}, p=0.999$ ). Looking at their distributions (Figure 2,
TABLE 7 | Differences and 95\% confidence intervals for comparisons between grassland HNVFs and other nHNVF soil types in Atlantic Europe.

\begin{tabular}{|c|c|c|c|c|}
\hline & \multirow{2}{*}{$\begin{array}{l}\Delta \text { SOC } \\
\mathrm{g} \mathrm{kg}^{-1}\end{array}$} & \multicolumn{2}{|c|}{$95 \% \mathrm{Cl}$} & \multirow[t]{2}{*}{$p$} \\
\hline & & Lower & Upper & \\
\hline$n H N V F \times W S C-H N V F \times G$ & -27.83 & -39.05 & -16.61 & $<0.001$ \\
\hline $\mathrm{nHNVF} \times \mathrm{OC}-\mathrm{HNVF} \times \mathrm{G}$ & -26.95 & -41.85 & -12.05 & $<0.001$ \\
\hline $\mathrm{nHNVF} \times \mathrm{SC}-\mathrm{HNVF} \times \mathrm{G}$ & -25.77 & -38.73 & -12.80 & $<0.001$ \\
\hline$n H N V F \times R T C-H N V F \times G$ & -28.21 & -45.64 & -10.78 & $<0.001$ \\
\hline$n H N V F \times V-H N V F \times G$ & -30.63 & -54.39 & -6.87 & $<0.001$ \\
\hline$n H N V F \times V I C-H N V F \times G$ & -28.11 & -50.43 & -5.80 & $<0.001$ \\
\hline $\mathrm{nHNVF} \times \mathrm{G}-\mathrm{HNVF} \times \mathrm{G}$ & -12.78 & -24.16 & -1.40 & 0.005 \\
\hline
\end{tabular}

Atlantic Europe panel) one would expect this difference to be substantial. The reason for this outcome is that the two samples are unbalanced and in these cases the Tukey test is conservative. In Continental Europe the grassland HNVFs show the highest content in organic carbon. Significant differences between HNVFs and nHNVFs emerged only when grassland nHNVFs were compared with nHNVFs, irrespective of the crop type. Table 8 summarizes this evidence.

In the Baltic and Scandinavia region the comparison between HNVFs and nHNVFs yielded one significant difference only (i.e., between nHNVF OC and HNVF WSC: difference $=-27.95, p=$ 0.049). Grassland HNVFs seem not to hold the capacity to store significantly more carbon than other soils either in the HNVF and nHNVF categories, although the comparison of grassland HNVFs with WSC nHNVFs was close to the significance level $(p=0.054)$. The Mediterranean region is characterized by soils that tend to contain less carbon than the overall mean value of HNVFs (Figure 2, dashed line). This holds for both HNVFs and nHNVFs, although grassland HNVFs tend to reach that value. Grassland HNVFs contain significantly more carbon than WSC nHNVFs (difference $=14.16 \mathrm{~g} \mathrm{SOC} \mathrm{kg}^{-1}, p=0.009$ ).

Although HNVFs store more carbon than nHNVFs overall and in each and every single region (see Table 4), when the variability due to various land uses is incorporated this evidence becomes more heterogeneous across regions. In particular, the number of significant differences between HNVFs and nHNVFs, when associated with the various crop types, is higher in the UKI regions (seven significant comparisons), ECO (seven) and CON (eight). This is mainly due to the contribution of grassland HNVFs. All the significant differences between HNVFs and nHNVFs in these areas in fact emerge when HNVFs are in association with grasslands. In MED region as well as in the Baltic and Scandinavia only one significant comparison emerged between HNVFs and nHNVFs when considering the different land uses.

\section{DISCUSSION}

The HNVF concept introduced in the 1990s (Baldock et al., 1993; Beaufoy et al., 1994) was intended as an approach to differentiate the agricultural systems based on their contribution to nature conservation. It is one expression of the multifunctional 
TABLE 8 | Differences and 95\% confidence intervals for comparisons between grassland HNVFs and other nHNVF soil types in Continental Europe.

\begin{tabular}{|c|c|c|c|c|}
\hline & \multirow{2}{*}{$\begin{array}{l}\Delta \text { SOC } \\
\mathrm{g} \mathrm{kg}^{-1}\end{array}$} & \multicolumn{2}{|c|}{$95 \% \mathrm{Cl}$} & \multirow[t]{2}{*}{$p$} \\
\hline & & Lower & Upper & \\
\hline$n H N V F \times W S C-H N V F \times G$ & -36.30 & -44.82 & -27.78 & $<0.001$ \\
\hline$n H N V F \times F C-H N V F \times G$ & -32.17 & -48.12 & -16.22 & $<0.001$ \\
\hline$n H N V F \times F B-H N V F \times G$ & -32.05 & -60.99 & -3.11 & 0.007 \\
\hline$n H N V F \times G-H N V F \times G$ & -16.82 & -25.94 & -7.70 & $<0.001$ \\
\hline $\mathrm{nHNVF} \times \mathrm{OC}-\mathrm{HNVF} \times \mathrm{G}$ & -35.66 & -48.00 & -23.32 & $<0.001$ \\
\hline$n H N V F \times R T C-H N V F \times G$ & -36.52 & -51.75 & -21.29 & $<0.001$ \\
\hline $\mathrm{nHNVF} \times \mathrm{SC}-\mathrm{HNVF} \times \mathrm{G}$ & -33.96 & -44.64 & -23.28 & $<0.001$ \\
\hline
\end{tabular}

role of agriculture, but also represents an indication of land use/land management intensity of agricultural systems. Land use intensity, within agricultural systems, is determined by the frequency and the intensity of anthropogenic activities, such as soil tillage, fertilization, irrigation, and pesticides application. Land management intensity can be estimated, for example, from the level of mechanization or specialization or the amount of inputs used (Donald et al., 2001). The hypothesis we tested was that soils in HNVF contain more organic carbon than nHNVF. In addition, we investigated how land use/crop types and geographic regions may affect this difference. The results of our analysis showed that, globally, the HNVF soils are characterized by higher organic carbon contents compared to nHNVFs. This evidence corroborates the fact that less intensively managed agroecosystems increase the potential of soils to accumulate carbon (Soussana et al., 2004; Rees et al., 2005; Grandy and Robertson, 2007; Ostle et al., 2009; Muñoz-Rojas et al., 2015) and deliver more ecosystem services (Björklund et al., 1999). The intensity of the management is generally related to the amount of inputs used, although not all inputs have the same effect on SOC storage. The intensity of tillage is generally inversely related to SOC storage (Govaerts et al., 2009), with no/minimum tillage systems storing more carbon than conventional tillage systems; however, other reviews showed the absence of significant differences between conventional and no-tillage systems. The effect of fertilization can be extremely variable. On grasslands nitrogen fertilization seems to reduce SOC content (Rees et al., 2005), while on arable lands inorganic fertilization generally increases the SOC content (Ludwig et al., 2010).

Our results indicate that also land use/crop type and the geographic regions are important factors influencing SOC content, confirming other scientific evidence (Xiao et al., 1997; Smith et al., 2005; Scharlemann et al., 2014; Lugato et al., 2015; Wiesmeier et al., 2015). The influence of these factors, which is highlighted by the results of the Tukey tests, is such that HNVFs and nHNVFs do not appear as sharply distinct categories as for carbon storage potential, but their performance is heavily affected by the other two factors. In particular, the pattern that seems to emerge is that HNVF shows significantly higher carbon content than $\mathrm{nHNVF}$ across regions when the land use is grassland (see Figure S2). This holds with the exception of the Baltic and Scandinavia region. Several estimates of SOC densities and stocks at global scale have been published and showed a clear relation between latitude, climate, and SOC (Batjes, 1996; Scharlemann et al., 2014). On a global scale boreal moist and cool temperate moist are the climate types allowing to store more carbon in soil (Scharlemann et al., 2014). The differences between HNVFs and nHNVFs are larger in UK and Ireland, Continental Europe and Atlantic Europe, while in the Mediterranean, Scandinavia, and Baltic regions are less pronounced. The specific outcomes for UK and Ireland require further reflection. Grasslands in UKI region show the largest differences in SOC content between HNVFs and nHNVFs (63.6 g $\mathrm{kg}^{-1}$ ). The majority of HNVF areas of the UK are in the Northern and Western Great Britain (mainly in Scotland and Wales) and in Ireland are located on the Atlantic west coast where the average rainfall is much higher than in the Southern and Eastern part ( $>1600$ and $<800 \mathrm{~mm}$, respectively). It is demonstrated that wet and cold climates promote the accumulation of organic carbon in soil. Guo and Gifford (2002), in a meta-analysis on the effects of land use change on carbon storage, indicated that the highest potential for increasing SOC storage is associated with rainfall ranging between 1000 and $3000 \mathrm{~mm}$ per year. In addition, these areas are characterized by difficult terrain (e.g., steep slopes). Because of cold and wet climate, decomposition of organic matter is slower, while intrusive tillage is unlikely because of difficult terrain and because the climate makes tillage crops less profitable. These areas were classified as HNVF because they are marginal and in most of the cases low intensity is the only possible management. Soil characteristics and climatic factors associated to this "marginality" act in synergy with low intensity management to make SOC content high. Our results, combined with this evidence, recall the issue of the characterization of HNVF. In certain areas high carbon content and the classification of a soil as HNVF are not linked causally but co-occur because no other farmland is possible there. In the Mediterranean region soils tend to accumulate less carbon, irrespective of land management. This suggests that the potential to increase SOC content by land management practices is higher in Central Europe (Continental and Atlantic Europe) and UKI, compared to Southern or Northern Europe. This evidence is also confirmed by other researches on a European scale, such as the scientific and technical report of JRC on "Carbon Sink Enhancement in Soils of Europe" (Stolbovoy et al., 2007).

In general SOC content is the highest in grasslands. Also, the largest differences in SOC content between HNVFs and nHNVFs occur with grasslands (FC in BS region is the only exception). This confirms what previously documented in the literature (Scurlock and Hall, 1998; Soussana et al., 2004; Smith et al., 2005). In a recent modeling exercise at EU level, Lugato et al. (2015) posited that conversion of arable lands in grasslands is most effective in increasing carbon storage in agricultural soils. In the EU28 the area of permanent grasslands is 60 million ha and, on average, HNVFs cover $32 \%$ of the EU agricultural area. If we consider the possibility of increasing the percentage of HNVFs up to $50 \%$, only for grasslands $(+10.5$ million ha) the benefit in 
terms of carbon storage would be $\sim 0.4 \mathrm{Gt}^{-1}(0-30 \mathrm{~cm}$; bulk density $1.3 \mathrm{~g} \mathrm{~cm}^{-3}$ ). Our analysis demonstrates that the HNVF management type can further increase the potential of grasslands in terms of carbon storage. The particularly high SOC content of permanent crops can be explained with the limited impact of soil tillage of these crops/land uses compared to the annual crops. It should be noticed, however, that recent researches showed that the role of no-tillage was often overestimated, while the potential of root apparatus as source of organic carbon inputs to the soil has often been underestimated (Giller et al., 2015). It is important to consider, however, that the classification/mapping exercise of HNVFs at continental scale is mainly able to detect differences on landscape level while very often, especially within the arable systems, the differences in management can be at the level of individual farms. In other words, the presence of an agro-ecological/organic/conservative farm within an intensively managed matrix/landscape cannot be detected and this is true also for the opposite case (i.e., an intensive farm within a less intensive landscape). This is particularly evident for arable systems where the different management options can play a major role at farm/field scale (conservation tillage, use of organic amendments, organic farming, etc.), while for grasslands the most relevant differences are operated at landscape/regional scale (grazing or non-grazing systems, agroforestry systems, etc.).

The peculiarity and added value of the results presented here is that they are produced based on a continental scale analysis. Such analysis has been carried out using a very large dataset and by comparing two land management systems. This research, however, also shows some limitations in the classification and mapping exercise of HNVF or, more in general, of agricultural systems at a continental scale. Indeed, at this level of spatial resolution it is not possible to detect variations in management practices that can have a relevant impact on SOC content and often occur at farm/field scale. Consequently, a more accurate evaluation of SOC content as function of different types of land/agricultural management should be done

\section{REFERENCES}

Andersen, E., Baldock, D., Bennett, H., Beaufoy, G., Bignal, E., Brouwer, F., et al. (2003). Developing a High Nature Value Indicator. Report for the European Environment Agency, Copenhagen. Available online at: http://www.eea.europa. $\mathrm{eu} /$ data-and-maps/indicators/agriculture-area-under-management-practices/ developing-a-high-nature-value

Andersen, E., Elbersen, B., Godeschalk, F., and Verhog, D. (2007). Farm management indicators and farm typologies as a basis for assessments in a changing policy environment. J. Environ. Manag. 82, 353-362. doi: 10.1016/j.jenvman.2006.04.021

Baldock, D., Beaufoy, G., Bennett, G., and Clark, J. (1993). Nature Conservation and New Directions in the Common Agricultural Policy. London: Institute for European Environmental Policy.

Batjes, N. H. (1996). Total carbon and nitrogen in the soils of the world. Eur. J. Soil Sci. 47, 151-163. doi: 10.1111/j.1365-2389.1996.tb01386.x

Beaufoy, G., Baldock, D., and Clark, J. (1994). The Nature of Farming. Low Intensity Farming Systems in Nine European Countries. Report IEEP/WWF/JNCC, London; Gland; Peterborough, ON. at more detailed scale (i.e., watershed), replicated in different environmental conditions, and then up-scaled. Furthermore, it appears evident the intrinsic difference between the two datasets and the parameters/classifications used: while the measure of SOC content (or other soil parameters) is an objective and unambiguous metric, the classification of HNVF areas can be biased. HNVFs often are not the result of agricultural management deliberately adopted, but are the consequence of intrinsic limiting factors of the land.

\section{AUTHOR CONTRIBUTIONS}

CG experimental design, data extraction and analysis, literature review, manuscript preparation. CM literature review, manuscript preparation. GV literature review, manuscript preparation. FC literature review, manuscript preparation. $\mathrm{AB}$ statistical analysis, manuscript preparation. MS statistical analysis.

\section{ACKNOWLEDGMENTS}

We acknowledge the Joint Research Centre of the European Commission for providing the HNVF map of EU (M.L. Paracchini) and for the LUCAS Soil Dataset (L. Montanarella, G. Toth, A. Jones, and P. Panagos). This study was conducted as part of the LANDMARK (LAND Management: Assessment, Research, Knowledge Base) project. LANDMARK has received funding from the European Union's Horizon 2020 research and innovation programme under grant agreement No 635201. Dr. Jed Borowski is also acknowledged for language revision.

\section{SUPPLEMENTARY MATERIAL}

The Supplementary Material for this article can be found online at: http://journal.frontiersin.org/article/10.3389/fenvs. 2016.00047
Björklund, J., Limburg, K. E., and Rydberg, T. (1999). Impact of production intensity on the ability of the agricultural landscape to generate ecosystem services: an example from Sweden. Ecol. Econ. 29, 269-291. doi: 10.1016/S09218009(99)00014-2

Burnham, K. P., and Anderson, D. R. (1998). Model Selection and Multimodel Inference: A Practical Information-Theoretic Approach. New York, NY: Springer-Verlag.

Daily, G. C., Matson, P. A., and Vitousek, P. M. (1997). "Ecosystem services supplied by soils," in Nature's Services: Societal Dependence on Natural Ecosystems, ed G. C. Daily (Washington, DC: Island Press), $113-132$.

Donald, P. F., Green, R. E., and Heath, M. F. (2001). Agricultural intensification and the collapse of Europe's farmland bird populations. Proc. Biol. Sci. 268, 25-29. doi: 10.1098/rspb.2000.1325

EEA-ETC/TE (2002). CORINE Land Cover Update. I\&CLC2000 Project, Technical Guidelines, Copenhagen.

Egoh, B., Reyers, B., Rouget, M., Bode, M., and Richardson, D. M. (2009). Spatial congruence between biodiversity and ecosystem services in South Africa. Biol. Conserv. 142, 553-562. doi: 10.1016/j.biocon.2008.11.009 
Egoh, B., Reyers, B., Rouget, M., Richardson, D. M., Le Maitre, D. C., and van Jaarsveld, A. S. (2008). Mapping ecosystem services for planning and management. Agric. Ecosyst. Environ. 127, 135-140. doi: 10.1016/j.agee.2008.03.013

Eswaran, H., van den Berg, E., and Reich, P. (1993). Organic carbon in soils of the World. Sol. Sci. Soc. Am. J. 57, 192-154. doi: 10.2136/sssaj1993.03615995005 $700010034 \mathrm{x}$

EUROSTAT (2015). LUCAS 2015 (Land Use/Cover Area Frame Survey). Available online at: http://ec.europa.eu/eurostat/documents/205002/6786255/ LUCAS2015-C3-Classification-20150227.pdf/969ca853-e325-48b3-9d59$7 \mathrm{e} 86023 \mathrm{~b} 2 \mathrm{~b} 27$

Giller, K. E., Andersson, J. A., Corbeels, M., Kirkegaard, J., Mortensen, D., Erenstein, O., et al. (2015). Beyond conservation agriculture. Front. Plant Sci. 6:870. doi: 10.3389/fpls.2015.00870

Govaerts, B., Verhulst, N., Castellanos-Navarrete, A., Sayre, K. D., Dixon, J., and Dendooven, L. (2009). Conservation agriculture and soil carbon sequestration: between myth and farmer reality. Crit. Rev. Plant Sci. 28, 97-122. doi: 10.1080/07352680902776358

Grandy, A. S., and Robertson, G. P. (2007). Land-use intensity effects on soil organic carbon accumulation rates and mechanisms. Ecosystems 10, 59-74. doi: 10.1007/s10021-006-9010-y

Guo, L. B., and Gifford, R. M. (2002). Soil carbon stocks and land use change: a meta analysis. Glob. Change Biol. 8, 345-360. doi: 10.1046/j.13541013.2002.00486.x

International Organization for Standardization (ISO) (1995). Soil Quality Determination of Organic and Total Carbon after Dry Combustion (Elementary Analysis). Geneva: ISO.

Jongman, R. H. G., Bunce, R. G. H., Metzger, M. J., Mücher, C. A., Howard, D. C., and Mateus, V. L. (2006). Objectives and applications of a statistical environmental stratification of Europe. Landsc. Ecol. 21, 409-419. doi: 10.1007/s10980-005-6428-0

Karlen, D. L., Mausbach, M. J., Doran, J. W., Cline, R. G., Harris, R. F., and Schuman, G. E. (1997). Soil quality: a concept, definition, and framework for evaluation (a Guest Editorial). Soil Sci. Society Am. J. 61, 4-10. doi: 10.2136/sssaj1997.03615995006100010001x

Lavelle, P., Decaëns, T., Aubert, M., Barot, S., Blouin, M., Bureau, F., et al. (2006). Soil invertebrates and ecosystem services. Eur. J. Soil Biol. 42, s3-s15. doi: 10.1016/j.ejsobi.2006.10.002

Lomba, A., Guerra, C., Alonso, J., Honrado, J. P., Jongman, R., and McCracken, D. (2014). Mapping and monitoring high nature value farmlands: challenges in European landscapes. J. Environ. Manag. 143, 140-150. doi: 10.1016/j.jenvman.2014.04.029

Ludwig, B., Hu, K., Niu, L., and Liu, X. (2010). Modelling the dynamics of organic carbon in fertilization and tillage experiments in the North China Plain using the Rothamsted Carbon Model-initialization and calculation of C inputs. Plant Soil 332, 193-206. doi: 10.1007/s11104-010-0285-6

Lugato, E., Bampa, F., Panagos, P., Montanarella, L., and Jones, A. (2015). Potential carbon sequestration of European arable soils estimated by modelling a comprehensive set of management practices. Glob. Change Biol. 20, 3557-3567. doi: $10.1111 /$ gcb. 12551

Marks, E., Aflakpui, G. K. S., Nkem, J., Poch, R. M., Khouma, M., Kokou, K., et al. (2009). Conservation of soil organic carbon, biodiversity and the provision of other ecosystem services along climatic gradients in West Africa. Biogeosciences 6, 1825-1838. doi: 10.5194/bg-6-1825-2009

Matson, P. A., Parton, W. J., Power, A. G., and Swift, M. J. (1997). Agricultural intensification and ecosystem properties. Science 277, 504-509. doi: $10.1126 /$ science. 277.5325 .504

Millennium Ecosystem Assessment (MEA) (2005). Ecosystem and Human Wellbeing: Synthesis. Washington, DC: Island Press.

Metzger, M. J., Bunce, R. G. H., Jongman, R. H. G., Mücher, C. A., and Watkins, J. W. (2005). A climatic stratification of the environment of Europe. Glob. Ecol. Biogeogr. 14, 549-563. doi: 10.1111/j.1466-822X.2005. 00190.x

Muñoz-Rojas, M., Jordán, A., Zavala, L. M., De la Rosa, D., Abd-Elmabod, S. K., and Anaya-Romero, M. (2015). Impact of land use and land cover changes on organic carbon stocks in Mediterranean soils (1956-2007). Land Degrad. Dev. 26, 168-179. doi: 10.1002/ldr.2194
Naidoo, R., Balmford, A., Costanza, R., Fisher, B., Green, R. E., Lehner, B., et al. (2008). Global mapping of ecosystem services and conservation priorities. Proc. Natl. Acad. Sci. U.S.A 105, 9495-9500. doi: 10.1073/pnas.07078 23105

Ostle, N. J., Levy, P. E., Evans, C. D., and Smith, P. (2009). UK land use and soil carbon sequestration. Land Use Policy 26, S274-S283. doi: 10.1016/j.landusepol.2009.08.006

Palm, C. A., Myers, R. J., and Nandwa, S. M. (1997). “Combined use of organic and inorganic nutrient sources for soil fertility maintenance and replenishment," in Replenishing Soil Fertility in Africa, eds J. R. Buresh, P. A. Sanchez, and F. Calboun (Madison, WI: ASA, CSSA, SSA Special Publication 51), 193-217.

Panagos, P., Ballabio, C., Yigini, Y., and Dunbar, M. B. (2013). Estimating the soil organic carbon content for European NUTS2 regions based on LUCAS data collection. Sci. Total Environ. 442, 235-246. doi: 10.1016/j.scitotenv.2012.10.017

Paracchini, M. L., Petersen, J.-E., Hoogeveen, Y., Bamps, C., Burfield, I., and Van Swaay, C. (2008). High Nature Value Farmland in Europe. An Estimate of the Distribution Patterns on the Basis of Land Cover and Biodiversity Data. JRC Scientific and Technical Reports. Joint Research Centre - Institute for Environment and Sustainability, 87.

Peneva, M., Draganova, M., Gonzalez, C., Diaz, M., and Mishev, P. (2014). "High nature value farming: environmental practices for rural sustainability," in Transition Pathways Towards Sustainability in Agriculture: Case Studies from Europe, eds L. A. Sutherland, I. Darnhofer, G. Wilson, and L. Zagata (Wallingford, UK: CABI), 97-112.

Plieninger, T., and Bieling, C. (2013). Resilience-based perspectives to guiding high-nature-value farmland through socioeconomic change. Ecol. Soc. 18, 20. doi: 10.5751/es-05877-180420

Pointereau, P., Paracchini, M. L., Terres, J.-M., Jiguet, F., Bas, Y., and Biala, K. (2007). Identification of High Nature Value farmland in France Through Statistical Information and Farm Practice Surveys. JRC Scientific and Technical Reports. Joint Research Centre-Institute for Environment and Sustainability, 76.

Rees, R. M., Bingham, I. J., Baddeley, J. A., and Watson, C. A. (2005). The role of plants and land management in sequestering soil carbon in temperate arable and grassland ecosystems. Geoderma 128, 130-154. doi: 10.1016/j.geoderma.2004.12.020

Scharlemann, J. P. W., Tanner, E. V. J., Hiederer, R., and Kapos, V. (2014). Global soil carbon: understanding and managing the largest terrestrial carbon pool. Carbon Manag. 5, 81-91. doi: 10.4155/cmt.13.77

Scurlock, J. M. O., and Hall, D. O. (1998). The global carbon sink: a grassland perspective. Glob. Change Biol. 4, 229-233. doi: 10.1046/j.13652486.1998.00151.x

Smith, J. O., Smith, P., Wattenbach, M., Zaehle, S., Hiederer, R., Jones, R. J., et al. (2005). Projected changes in mineral soil carbon of European croplands and grasslands, 1990-2080. Glob. Change Biol. 11, 2141-2152. doi: 10.1111/j.13652486.2005.001075.x

Soussana, J.-F., Loiseau, P., Vuichard, N., Ceschia, E., Balesdent, J., Chevallier, T., et al. (2004). Carbon cycling and sequestration opportunities in temperate grasslands. Soil Use Manag. 20, 219-230. doi: 10.1111/j.1475-2743.2004. tb00362.x

Stolbovoy, V., Montanarella, L., and Panagos, P. (2007). Carbon Sink Enhancement in Soils of Europe: Data, Modeling, Verification, Vol. 186. Joint Research Centre Repots, Institute for Environment and Sustainability.

Tóth, G., Jones, A., and Montanarella, L. (2013). LUCAS Topsoil Survey. Methodology, Data and Results. JRC Technical Reports. Publications Office of the European Union, EUR26102 - Scientific and Technical Research series.

Trisorio, A., and Borlizzi, A. (2011). "Assessing the impact of rural policy on biodiversity: high nature value farming in Italy," in 122nd EAAE Seminar Evidence-Based Agricultural and Rural Policy Making, Vol. 9 (Ancona).

Tsiafouli, M. A., Thébault, E., Sgardelis, S. P., de Ruiter, P. C., van der Putten, W. H., Birkhofer, K., et al. (2015). Intensive agriculture reduces soil biodiversity across Europe. Glob. Change Biol. 21, 973-985. doi: 10.1111/gcb. 12752 
Van Swaay, C. A. M., and Warren, M. S. (2003). Prime Butterfly Areas in Europe: Priority sites for Conservation. National Reference Centre for Agriculture, Nature and Fisheries, Ministry of Agriculture, Nature Management and Fisheries, Wageningen.

Wiesmeier, M., von Lützow, M., Spörlein, P., Geuß, U., Hangen, E., Reischl, A., et al. (2015). Land use effects on organic carbon storage in soils of Bavaria: the importance of soil types. Soil Till. Res. 146, 296-302. doi: 10.1016/j.still.2014.10.003

Xiao, X., Kicklighter, D. W., Melillo, J. M., McGuire, A. D., Stone and Sokolov, A. P. (1997). Linking a global terrestrial biogeochemical model and a 2-dimensional climate model: implications for the global carbon budget. Tellus 49, 18-37. doi: 10.1034/j.1600-0889.49.issue1.2.x

Zech, W., Senesi, N., Guggenberger, G., Kaiser, K., Lehmann, J., Miano, T. M., et al. (1997). Factors controlling humification and mineralization of soil organic matter in the tropics. Geoderma 79, 117-162. doi: 10.1016/S00167061(97)00040-2

Conflict of Interest Statement: The authors declare that the research was conducted in the absence of any commercial or financial relationships that could be construed as a potential conflict of interest.

Copyright $\odot 2016$ Gardi, Visioli, Conti, Scotti, Menta and Bodini. This is an openaccess article distributed under the terms of the Creative Commons Attribution License (CC BY). The use, distribution or reproduction in other forums is permitted, provided the original author(s) or licensor are credited and that the original publication in this journal is cited, in accordance with accepted academic practice. No use, distribution or reproduction is permitted which does not comply with these terms. 